\title{
Key Performance Indicators as an Instrument of Achieving Strategic Indicators of Oil and Gas Producers
}

\author{
Elena Marsovna Deberdieva
}

Tyumen State Oil and Gas University, 625000, Russia, Tyumen, Volodarskogo st., 38

\section{Doi:10.5901/mjss.2015.v6n3s3p19}

\section{Abstract}

The papers addresses the issues of KPI system use with respect to achieving oil and gas producers' target strategic indicators of development and operation. Background to key performance indicators system implementation in oil and gas producers is explained. It is demonstrated that key performance indicators structured in terms of distinguished prospects of Balanced Scorecard allows achieving milestones because of their use both at all levels of management hierarchy and production and technological chain. For this purpose results of recommended instruments implementation in world major companies are given. In the course of literature review it's shown that KPI and BSC not only promote the company's strategy realization but allow choosing from possible strategies the preferred one. The paper reveals strong interrelation of KPI with other management instruments: BSC and budgeting as well as expediency of their joint use. Approaches to KPI selection, its classification and sequence of project development regarding KPI and BSC implementation are examined. In the framework of preparatory stage of key performance indicators selection for the oil and gas company, its goals decomposition and also structuring in terms of main business segment - extraction of oil - are represented. Results of academic and research study are given. They involve explanation of current prospects of BSC of territorial department of crude oil production: finances, production, ecology and staff; definition of specific goals and development of key performance indicators for each of stated prospect.

Keywords: Key Performance Indicators (KPI), Balanced Scorecard (BSC), oil-and-gas production enterprise, production unit, strategy, strategic indicators, management tools.

\section{Introduction}

Sustainable development of enterprises in any business segment is impossible without designing long-term strategy and assuring strategic partnership with related production units. In recent decades the significance of corporate entities' strategic vision allowing them to survive at competitive struggle in the long-term has surged. Intensification of competition, fast-changing environment require not only designing and continuous adjusting corporate strategy but focusing on the company's internal state. Vertical integration is typical for oil-and-gas production enterprises, it requires coordination of relations between isolated enterprises, which comprise technological complex and take part in end-product value chain that in its turn complicates the processes of development and implementation of elaborated strategic decisions. Moreover, current organizational changes caused by merger and acquisition processes, business combination and integration of its units, allotment of non-core assets, etc. demand the use of specific and adaptation of traditional approaches to company management in general and management of enterprises entering technologic and organizational holdings.

Currently the world practice offers a wide range of instruments that allow harmonizing companies' and their units' economic interests: budgeting, Controlling, Balanced Scorecard and others. For today the management system based on key performance indicators (KPI) is one of the most effective systems from a perspective of complex-structured enterprises management. It helps to channel the company's activity in general and its units to achieve strategic goals, increase processes performance and estimate their efficiency. In the framework of a big corporation the system of key performance indicators make it possible to evaluate the contribution of each unit in achieving corporate-wide goals, to provide communication between units and establish strategic management scheme.

\section{Literature Review}

Key performance indicators as an instrument of various management concepts are wide spread in world management practice. Among these concepts there are Drucker' purpose management (Drucker P., 2007); Hubert K. Rampersad's Total Performance Scocard (Rampersad H., 2003); Balanced Scorecard coupled with Maisei'a strategic map model 
(Maisei L., 1992) developed by Kaplan R. and Norton D. (Kaplan and Norton, 2004); performance management and others.

According to researchers in the area of complex structured enterprises management activity assessment of units and the company in general have a massive impact on the organization. At the same time it is one of the most weakly developed areas of management (Drucker, 2007). Conducted researches show that $80 \%$ of Russian top managers are dissatisfied with current performance evaluation systems, which for the most part do not reflect interrelation between plans, their implementation, outcome and motivation (Klochkov, 2010). This problem can be solved by the use of key performance indicators. According to Parmenter D. the system of KPI includes many management concepts and complements Drucker's classic approach (Parmenter, 2007).

Drucker P. is considered a founder of evaluation system of results achievement based on "key" indicators. He proved the need for managers' refocusing from current issues on results achievement. In their turn, Robert Kaplan and David Norton proved that traditional accounting indicators do not reflect real picture of companies' performance (Kaplan and Norton, 1996). The authors revealed flaws of companies' management approaches and suggested 20 criteria of evaluation to provide company's performance balance.

When developing Balanced Scorecard, Hope and Fraser suggested using no more than 10 key effectiveness indicators, to 80 production indicators and 10 key performance indicators. Applying this approach to organization units, Panov M.M. recommends using no more than $10-15 \mathrm{KPI}$ with a view to rationalizing plan and supervising functions of management.

Studying the process of key indicators selection in the area of personnel management in accordance with organization's set tasks, Becker B., Huselid M., Ulrich D. found that generally evaluation indicators do not correlate with organization's goals (Becker et al., 2007). Similar situation is observed in other management lines.

The use of KPI allows not only focusing the company and its units on achievement strategic milestones but choosing the preferred strategy of development. In such a manner, the complex of goal-oriented criteria of oil and gas company's development in terms of levels of management hierarchy based on which preferred variant of strategy is selected using the method of multicriteria optimization is studied in Lenkova's and Osinovskaya's work (Lenkova O.V. and Osinovskaya I.V, 2011).

The "Corporate development strategy of oil and gas company" monograph is concerned with recommendations for improving oil and gas companies' strategy realization, which is interrelated set of businesses (Deberdieva E.M. and $n$ Lenkova O.V., 2011). The paper reflects approaches to adaptation of management strategic instruments to business environment of oil economic entities, a complex of indicators for company's potential assessment in terms of technologic links is proposed, and recommendations for corporate strategy implementation based on developed scheme of its decomposition are elaborated.

Other works of Tyumen State Oil and Gas University scientists are concerned with individual aspects of oil and gas companies' strategy implementation based on the strategic cooperation of structural links aggregate. For example, "Development of corporate entities' management in oil and gas business" puts an emphasis on the formation of effective system of management and renewal of internal interaction mechanism based on various groups of estimative indicators. Approach to management decision making in oil and gas companies of complex structure with respect to production units' and company's interests are considered in a number of works of Plenkina V.V., Lenkova O.V. and Osinovskaya I.V. (Plenkina V.V. et al., 2013; Lenkova et al., 2011; Osinovskaya et al., 2013). Focus on providing conformity of strategic goals to production units' key performance indicators based on oil and gas company's goals cascading is presented in the work "Strategic maps as a planning basis in complex industrial oil and gas structures" (Deberdieva E.M., 2014).

Estimation procedure for oil and gas companies' resource strategy effectiveness with the use of BSC and KPI for the company's resource base state is considered in Isaeva's paper (Isaeva N.S., 2014).

\section{Methods}

\subsection{Interaction of KPI with other management systems}

Generally speaking, the process of goal definition, selection of operative directions, and decision-making reflect the essence of management. For the first time Drucker P. suggested to tie management process with goals in 1954. This conception was stated in his "Management by goals" (Drucker, 2007). With regard to modern business environment the base of this system is measuring and comparing current performance wit a set of stated strategic parameters. Given this, measures that were subsequently named "key indicators" should be formed based on "smart goals" principles, so-called SMAR-criteria (Doran, 1981). In other words, they should be specific for the company and its subdivisions; measurable; 
achievable; relate to unit's business area; have due dates. Moreover, goals should be established top-down for all levels of the company focusing on company's strategies and goals achievement company-wide. Another principle for goal indicators selection is their reasonable limitation: there shouldn't be too many goals. KPI are designed to estimate goals achievement.

Balanced scorecard system is a management system that allows relating general strategy of the company with operative management. It affects all aspects of company's activity: financial, consumer, economic, and innovative one. The authors of the system Robert Kaplan and David Norton suggest taking into account four main aspects of company's operation evaluation, such as customer service, financial activity, internal processes, as well as training and development - in the form of certain indicators set (Kaplan and Norton, 1996). The implementation of BCS system is justified on grounds of formulation of company's strategic goals reflecting its market power and also company's mission formalization. Balanced scorecard system is successfully applied by many major companies of complex management structure of various fields, among which there are Mobil, Hilton, Saatchi\&Saatchi, Canon, Motorola, Siemens, BMW Financial Service, etc.

Balanced scorecard system includes KPI necessary for each unit under supervision, which are usually company's units chosen based on technologic organizational or functional features. Thus, the following tasks are solved:

- company's strategy formalization and its transformation into specific goals, holding activities to achieve them, and indicators reflecting degree of set tasks completion;

- estimating relationships between strategic goals and operative management in terms of managerial functions (planning, accounting, monitoring, motivation);

- providing feedback that allows timely estimate strategy implementation and set strategic milestones achievement.

Moreover, this conception is integrated with the system of budgeting and is coupled with management methods focused on companies' performance improvement in general and its units, allows focusing units' and each employee's activities on achievements of company's goals (Permyakov Y., 2012).

The use of KPI and BSC for the purpose of strategic management makes it possible to gain certain competitive advantages due to of state-of-the-art technologies use in the area of production and management, company's operational efficiency monitoring (Davydenko E.A., 2008). Planning and coordination of units' and employees' actions when achieving company's strategic goals with the use of KPI and BSC allow coordinating a number of separate events cost-effectively and in the shortest possible time. The advantage of this approach is based on the possibility of current and regular monitoring over the company's strategy implementation, unification of isolated strategic milestones in a single package.

As a rule, there's interaction between KPI and BSC at the stage of company's strategy formalization and strategic map elaboration: recommended indicators can become a basis for sound strategy development providing goals allocation with regard to all company's business dimensions and their sustainable development.

The success of company's operation largely depends on personal performance of employees, who should know not only company's strategic goals but take part in intended strategy implementation. In this regard KPI can be integrated in the system of staff motivation. In addition, company management may use KPI and BSC to delegate powers and generate scheme of interaction between units.

\section{$3.2 \mathrm{KPI}$ selection approaches}

Management of companies of complex structure requires authority delegation regarding indicators management and assignment of responsibility for their achievement at all levels of management. Therefore it makes sense to use different classification of KPI.

Firstly, there's KPI differentiation into indicative indicators (indicators) and imperative (control) indicators. Number of indicative indicators should answer organization units' goals and processes and be both proactive and lagging ones. Imperative indicators are developed by the number of stated prospects. They are deferred and main indicators for higher authorities to monitor the operation of subordinate levels. Besides, in order to provide system integrity, the aggregate of indicative and control indicators should be defined for entire top-down management structure in advance (Pechenaya L.T and Bogomolova, 2007).

Secondly, when developing KPI it's necessary to divide indicators into strategic and normative ones. Achievement of target values of KPI of strategic nature has a great impact on the company's state. Strategic KPI characterize chosen strategy of development and are priority for the company. Values of normative KPI are used for monitoring within chosen short-term period. It should be noted that referring an indicator to strategic or normative depends on the company's chosen strategy. KPI division into strategic and normative ones is quite important for rationalization of resource allocation 
between business units.

Considerable adaptation of traditional management systems is necessary to make them applicable for Russian enterprises. For example, the use of traditional structure of BSC for national oil and gas companies is scarcely ever reasonable, because of their inner and exterior communications formalization complicacy and business peculiarities. Nonetheless, BSC application in a group of companies where each enterprise pursues their own aims, which not always correspond to general strategy of multilevel corporate structure, is expedient. The important moment when defining KPI is their decomposition by technologically organizational structure that assuring focus of the efforts of managers of all levels on corporate-wide strategy carrying out. In particular cases scorecards by units aren't formed. Sometimes, indicators not only by the company and units but by projects are used.

Upon the formation of all KPI, they are united in groups by the company and by its units in particular. A rule of thumb states that companies averagely measure performance based on 10-20 indicators, by 2-5 individual lines: financial component - $5(22 \%)$, client component - $5(22 \%)$, component of inner business processes - 8-10 (34\%), training and growth $-5(22 \%)$. About $80 \%$ of indicators are non-financial.

Selection of indicators for balanced operation and development results in the system of interrelated tables with KPI in their cells. Each indicator is calculated at certain intervals. Performance of one or another unit is defined by their values. When implementing KPI in management practice for the first time, it's sound to test the system for the purpose of estimation of selected indicators quality and new system adaptation to current ones. Given this, it's necessary to introduce in test operation main KPI, and then the rest. It allows analyzing how the developed system of indicators interacts with each of management sybsystems since detachment of systems is a cause of non-effective motivation of senior management for strategic goals achievement.

\subsection{Decomposition strategic goals for KPI development}

Importance of KPI level formulation and grounding dramatically increases when specifying requirements for strategic and operative management combination, providing expedient monitoring of company's operation and separate units, maximum coverage of critical area influencing strategy fulfillment. It makes sense to structure these indicators by groups that reflect oil and gas company's goals decomposition: indicators that characterize performing functions imposed on units; indicators that reflect unit' level of costs; indicators that characterize effectiveness of execution of unit's management function, etc. Thus, formed indicators should reflect effectiveness of company's operation in general and separate structural subdivisions, as well as their role in general goals achievement (Deberdieva E.M, 2014).

For this purpose the company's strategic goals should be divided into functional goals, and then grouped by fields and levels of management: by the company in general, its individual unite, particular projects and products (Fig. 1).

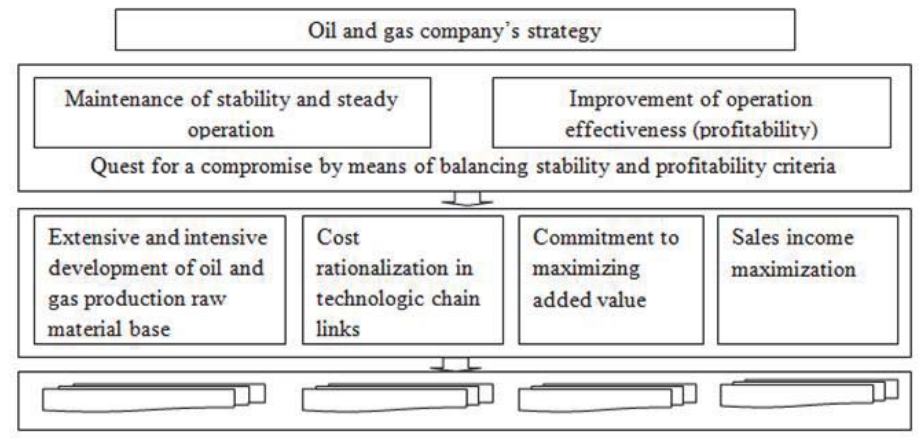

Fig 1. Part of oil and gas company's goals decomposition

After functional goals definition it's necessary to define key performance indicators that condition achievement of each of them. KPI can be both absolute and relative. Definition of specific KPI is usually task of managers assigned to one or other field of work, that's why clear-cut separation of their areas of responsibility is necessary. Managers' areas of responsibility are divided in such a way that each is responsible for one of company's goals achievement. If goals are balanced, managers can work as a single close-knit team. Unfortunately, as practice shows, owners or senior management somehow formalizes goals of top-level or at least comprehend them, but subgoals are usually set by managers of middle level independently on one another, if any.

Subsequently allotment of indicators by responsibility centers with regard to their functional specifics takes place, 
BU managers' KPI maps are plotted for further development of initiatives focused on KPI cost comparison on initiatives with an effect of sales in long-term period. After initiatives and adjustment of company's KPI level based on minimization of strategic budget risk index, company's annual budget, unit's annual budget and adjusted BU managers' KPI map are set. In strategic management economic effect of strategic initiatives realization is carried out through collateral performance of budget indicators and KPI of stated strategic horizon period. Formalization of cause-and-effect relation between KPI is carried out by means of coefficients calculated based on expert appraisal, statistical methods or both. When using KPI, indexes corresponding to additional development priorities such as level innovation, staff turnover, etc. form the basis of responsibility centers detection. As a rule, the center of cost, profit, profitinvestments give an account of conformity to planned cost, profit, relation of profit and investments; in uniform system financial responsibility centers are the same as responsibility centers for KPI achievement. Heads monitoring and incentives depend on the results of carrying out KPI by their units providing execution of development budget by the unit.

\section{Results}

\subsection{Background to KPI system implementation}

As carried out study shows, one of the most common problems of vertically-integrated oil and gas companies is holding's members' lack of organizational, informational and production unity. Despite the close connection of adjacent business processes by technologic feature, there are a number of problems in the area of company and its units management:

- in the modern context the system of economic relations between the units of oil and gas is organized on the basis of plan-budget process. Plan-budget system is an effective means for internal management, however, it doesn't provide solution for a number of principal issues of accounting, remunerative incentives and economic efficiency. The main drawback of internal plan-budget management is superfluous single-sourcing that leads to inefficiency of incentive system and lack of focus on general result;

- management strategy doesn't serve the modern purposes of companies', development, units' potential is fulfilled incompletely;

- understanding of corresponding management level's role and management place in the system of management not always corresponds to actual volume and nature of set tasks. Some current forms of management are obsolete, but new ones corresponding to time and situation aren't detected.

On the one hand, budget approach popular in management of oil and gas sector's structures of complex structure provides monitoring company's financial condition, provides heads with necessary information, allows estimating decisions taken by the managers of lower level, developing operative and strategic measures to adjust their operation. On the other hand, the system of budget management almost stays away from the company's strategy. Moreover, budgeting as a system of management has objective limitations, the main ones are poor use of non-financial indicators and focus on short-range tasks solution at the expense of long-term ones. That's why creation of high effective management system that meets transforming market's requirements is a critical mission. This requirement can be met using an instrument that makes it possible to get out company's strategy to each unit and each employee. It can be a management system based on key performance indicators (KPI) and BSC that proved its efficiency in many companies' practice.

Analysis of operation of corporations that got impressive results and stable position on the market has showed that these companies got to the top of the tree due to implementation of strategically oriented management based on BSC and KPI. "As a result of the poll conducted in 2001 by the English company of Business Intelligence among 200 successful companies in more than 20 countries of the world, $57 \%$ of respondents use Balanced Scorecard in management". According to Balanced Scorecard Collaborative, founded by Norton and Kaplan, as of the end of 2003 more than a half of companies that entering the list of 500 principal world firms compiled by the authoritative journal Fortune (particularly, AT \& T, Dell, Compaq, Motorola, Siemens) implemented this system" (Pereverzev N., 2003). There are following Russian companies, which use KPI in general system of performance management: "Mobilnye TeleSystemy", "Sumskor NPO imeni Frunze" JSC, public corporation "Rosatom", "SIBUR- Holding " JSC, "Gaspromneft" JSC, etc.

Background to implementation of KPI made a good showing in terms of BCS prospects in the enterprises of oil and gas sector of Russian economy is also supported by all oil companies' strategy and mission, given this, due to various reasons management of not all levels of management hierarchy is included in the process of strategic management. There are employees' incomprehension of company's strategic goals and lack of their participation in these goals achievement; lack of monitoring the process of enterprise's strategy implementation. Structural subdivisions often pursue 
their own aims, which not always correspond to uniform strategy of the company. Generation of strategic management system based on BSC and KPI will make it possible to achieve greater transparency of management that in its turn will promote more effective cooperation with potential investors and creditors when implementing large oil and gas projects.

\subsection{Oil and gas company structuring for KPI implementation}

As a rule vertical integration typical for Russian oil and gas companies involves formation of business segments' coordination center (sometimes with allocation of its function by several levels of management) in the field of planning, marketing, procurement, determination of ways and means of development with assignment of production operator's functions to member enterprises within the framework of chosen production areas of business, defining each participant's role in achieving shared industrial and commercial goals. A variant of multiple unit integrated structure management is a three-level system demonstrated by Lukoil JSC: the system of management at the holding level (the $1^{\text {st }}$ level of management) with focus on strategy planning and development functions performing, enterprise's current activity policy harmonization, monitoring and carrying out investment programs. The scheme of organizational structure of stated oil and gas company confirms the fact that strategy change and organizational structure are closely related. The company's strategy is the main factor that defines its organizational structure, multiobjective strategy complicates company's organizational structure, enhancement of which leads to efficiency of strategic tasks solution.

Management activity in the oil and gas company of complex structure is focused on:

- development of shared goals and objectives at all levels of management in keeping with consolidation policy;

- establishing optimal number of functions and levels of management focused on coordination and planning of subdivisions' activity;

- formation of structure for transaction costs system optimization;

- development of unified system of enterprises' performance accounting and monitoring, and, consequently, availability of current and qualitative information on company activity, availability of diagnostics of current adverse variances in company's operation, and therefore possibility of making sound management decisions;

- development of market system monitoring and, consequently, providing opportunity of active influence on market outlets of products with various added value;

- effective production process organization;

- organization of company's recourses efficient use based on resource conservation and energy efficiency policy, etc.

In case of vertical-integrated company it should be taken into account the greatest problems that arise in defining functions when describing powers of the $2^{\text {nd }}$ level of management: branches and territorial departments. As a rule, $2^{\text {nd }}$ level of management is responsible for the following functions: coordination of the system of production operators' actions; interaction with the center when determining long-term development of the complex and making suggestions regarding modernization in accordance with market requirements; marketing and resources provision; logistics center and some others. For example, the second level of management of companies of the "Lukoil" group consists of holdings differentiated by branches.

The system of management at the level of separate business units - the $3^{\text {rd }}$ level of managements - with priority of functions of the production operator responsible, for example, for production of planned volume and quality of oil, is presented with production operators and so-called areas for unified interbranch services delivery. These are automobile operating companies, service centers, social welfare centers. Thus, oil pumpers as a part of complex economical structures are territorial production oil producing organization (OPO). OPO have the status of "target costs center": from the central management office they receive centralized task by output; upper limit of cost per 1 ton of oil; level of transfer prices. Hence their powers are cut to a minimum; areas of supply and sale are centralized. In practice operational management of subdivisions is focused on the task of unit cost reduction by types of products within centrally established production program.

Thus, for the purpose of successful implementation of KPI system in the management practice of oil and gas enterprises of complex structure, it's recommended to structure the company by the levels of management reflecting the role of each level in achieving target strategic parameters. Moreover, taking into account specific nature of tasks within the types of activity of certain business entities and production units it appears reasonable to adjust the prospects of traditional BSC in regard to several of them. For example, ecological component of production operation is an important aspect for structural subdivision of the oil company. In this regard it's suggested to distinguish "Ecology" prospect for this level. 


\subsection{KPI implementation sequence}

Development and implementation of any system of indicators for multilevel corporate structure management has its peculiarities (Gershun A. and Gorsky, 2006). It's largely caused by the fact that company's management team needs to consider not only cross-effect of management goals within one subdivision or business segment but also cross-effect of different segments, and site conditions and interests as well. Within large corporations, which are oil and gas companies, balanced scorecard system allows estimating the contribution of each link in achieving corporate-wide goals, and also solving the issue of communication between group's companies and establishing clear scheme of strategic management. One of the main tasks of management is so-called "cascading" procedure, i.e. allocation of responsibility for achieving indicators by lower levels.

Direct implementation of KPI in OPO involves the following interrelated stages: creation of Coordination Council body for KPI system development and implementation - with the participation of management representatives; establishing working party - implementation body - for defining company's strategy clear to staff at all levels of management, and developing the complete list of corporate performance indicators, which will form the basis for individual processes management or company's units management. Coordination Council and working party develop OPO management models, calculation methods and indicators analysis company-wide based on strategic goals and corporate performance indicators. Subsequently they systematize data used for calculation, define accounting periods and form of presentation to higher level of management. The next step is formation of goals for chosen strategic period and goal tree for this period; selection of BSC prospects, strategic goals and indicators by prospects cascading, and map balance check.

Key indicators for each goal are defined after company's strategic map generation. At this stage both new indicators are developed and current ones are adjusted in compliance with strategic goals. The analysis of KPI application by a number of companies shows that enterprises used a great deal of indicators (especially, production ones), which duplicate each other, and sometimes even superfluous ones, that's why it's necessary to exclude them from the KPI list. Moreover, balanced map should include a complex of proactive and main lagging indicators, reflect their interrelation.

Indicators by separate types of activity do not provide their development objectives unless they are connected to current distinguished prospects of BSC and company's strategic goals. Interrelation between strategic goals and key performance indicators by four main activities is shown in Fig. 2.

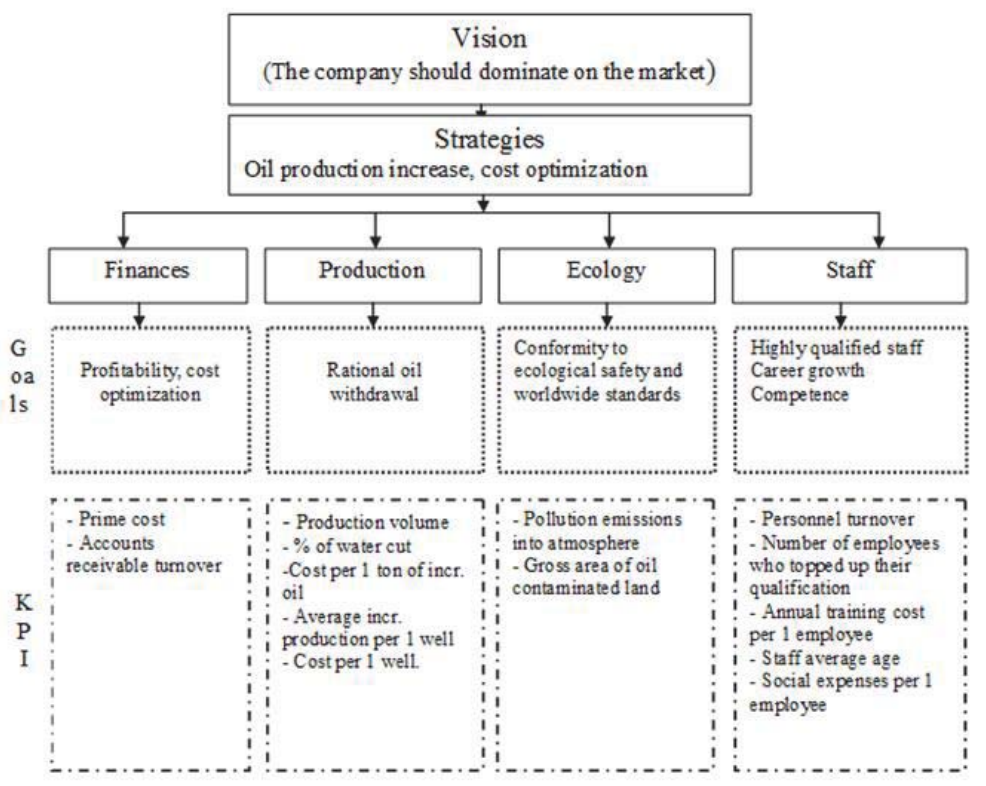

Fig 2. KPI and strategy interrelation

When indicators are connected, the process of rationing takes place, i.e. assignment of key values to indicators under management. Rationing should be carried out "top-down": from "Finances" to "Staff"; selection of dependent indicators' values is also carried our based on established connections. 


\subsection{KPI development results for TPOPE}

When developing implementation procedure of KPI integrated in BSC for the oil-and-gas production enterprise, the composition of evaluation prospects in accordance with specific nature of TPOPE (territorial production oil producting enterprise) activity was defined at the first stage, when designing the system special priority was given to the most applicable ones: finances, ecology, production, and staff. This classification is based on the use of matrix organization, which features both branch and executive (technological) units, which hold responsibility for oil and gas production. It is suggested to use BSC as a system of strategic management and instrument for regulation of units' operation depending on task hierarchy at a definite time period. Task hierarchy for specific unit by time intervals can be demonstrated by the "filter" for goals selection (Fig. 3).

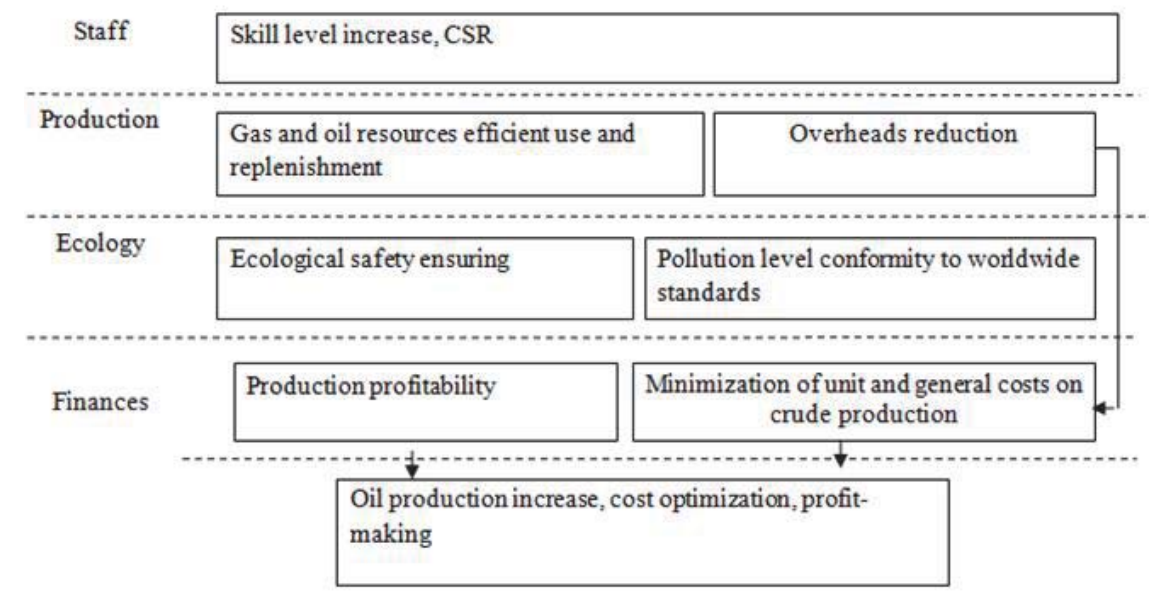

Figure 3. TPOPE goals cascading

The results of this stage are vision of desirable image of the company at given horizon period detailed by all companyrelevant aspects and formed goal structure of the highest level. The goal tree is structured in the form of goals system in respect to all interest groups, compulsory conditions and limitations, company's potential development goals, cost and material purposes of production and sales of higher order. The direction of holding's strategic development vector is detected at this stage. It was found that KPI system is a multilevel one. Its formation is carried out top-down and includes the following indicators: corporate indicators necessary for oil and gas company's executive management to evaluate business performance in general; financial indicators calculated for TPOPE; efficiency and performance indicators used to calculate financial indicators.

The carried out comparative analysis of several production units operation within a single holding made it possible to calculate target values for each indicator. Delphi approach helped to define weight of each performance indicator depending on the level of significance for the enterprise.

Thus, KPI is calculated for the "Production" prospect based on adjusted oil output, number of wells subject to optimization, defined number and names of measures for oil production optimization, and cost per 1 ton of commercial oil (Table 1).

Table 1. KPI "Production" aspect for TPOPE

\begin{tabular}{|l|c|c|}
\hline KPI name & Unit of measurement & Value $^{*}$ \\
\hline Oil output, total & thous. tons & 1391,9 \\
\hline Incremental oil production due to optimizations & thous. tons & 650,3 \\
\hline Number of optimizations & pieces & 775 \\
\hline Optimizations expenditures & money unit (MU) & 6325,1 \\
\hline Cost per 1 ton of incremental oil & MU /1 ton & 9,45 \\
\hline Average incremental oil production & thous. tons /1 well & 0,84 \\
\hline Average cost per 1 well & MU /1 well & 7,83 \\
\hline Water cut & $\%$ & 90,5 \\
\hline
\end{tabular}

* accounting period -1 year. 
Cost per 1 ton of incremental oil is calculated for entire company. Average incremental oil production per 1 well reflects incremental oil volume averagely produced due to 1 measure carrying out per accounting period. This indicator indirectly characterizes optimization income level and is a result of ratio between total production volume realized due to carrying out of measures and number of these measures. Incremental oil production is calculated according to approved methods "Incremental oil estimation" for the period under Investment activities regulations (Andreev A.F. et al., 2011).

As a result of carried out "brainstorming" total cost of commercial output and level of accounts receivable were chosen for key indicators by the "Finances" aspect.

For ecological safety ensuring according to local ecological monitoring projects it's necessary to monitor environment status, regularly take and process samples by all components of environment, determine heavy metals content, and recultivate oil contaminated lands. With regard to these requirements KPI for the "Ecology" prospect were developed.

It should be emphasized that each of proposed key performance indicators is recommended to regularly specify and adjust, recommended range of operation - from 1 month to 1 year. The manager can monitor operation of the area in his custody by the value of each performance indicator and eliminate possible problems at the stage of its originating.

Thus, the transparent and reliable scheme for indicators calculation, such as prime cost commercial oil, floating capital tiding up coefficient, was constructed for OPTPE. It allows objectively determining various planning parameters of key performance indicators used in the system of operations management by KPI.

\section{Discussion}

Change of internal and external conditions of oil and gas companies' operation requires adjusting management techniques at strategic and operational levels. Actual operating results running behind company's strategic milestone requires different approach to the mechanism for strategy implementation. In this regard the use of such instruments as KPI integrated in the system of Balanced Scorecard has distinct advantages. The use of the system of key performance indicators allows carrying out the process of authority delegation in a more rational way that is important in the context of entities of complex structures. As a result of KPI system implementation managers and employees have precise understanding of their duties and opportunity to control operating results by their own, certain interaction pattern between units appears, management transparency and conformity of individual goals to company's general strategic goals are provided.

The first three months of the use of proposed KPI system showed the following results (Table 2):

Table 2. KPI implementation results in TPOPE (extract)

\begin{tabular}{|l|c|}
\hline KPI & Increase in actual value, $\%$ \\
\hline "Production" prospect & $+15,2$ \\
\hline Oil output, total & $+10,2$ \\
\hline Incremental oil production due to optimizations & $+16,7$ \\
\hline$\ldots$ & $-19,7$ \\
\hline Average incremental oil production & $-1,8$ \\
\hline Average cost per 1 well & \\
\hline Water cut & $-8,2$ \\
\hline "Ecology" prospect & 0 \\
\hline Pollution emissions into atmosphere & \\
\hline Gross area oil contaminated land & \\
\hline$\ldots$ & $-35,2$ \\
\hline "Finances" prospect & $+18,2$ \\
\hline Capital floating tiding up coefficient & \\
\hline Accounts receivable & \multicolumn{1}{|c|}{} \\
\hline$\ldots$ & $-12,7$ \\
\hline "Staff" prospect & $+20,7$ \\
\hline Turnover rate & \\
\hline Number of employees who topped up their qualification & \\
\hline \multicolumn{2}{|c|}{} \\
\hline
\end{tabular}

Estimation of efficiency of KPI system implementation in chosen BSC prospects at the end of the first period revealed 
positive trend by certain indicators. At the same time a number of aspects require development of additional measures that will contribute to KPI achievement. However, the cause for non-achievement of performance indicators can be a change of external conditions and other objective reasons. Therefore, it should be taken into account that KPI development is not a one-time measure, it should be focused on and adapted to transforming business environment (both external and internal). Another critical moment is that desired efficiency based on implementation of the instruments under consideration can be achieved in case of their integrated - not partial - use.

\section{Conclusion}

The analysis of the leading oil and gas producer's operation and its territorial-production oil producing enterprises allows revealing main problems in current management techniques. Structuring of the company by various aspects and types of activity of units, which carry out a technological complex of works, was successful in formation of the system of key performance indicators for TPOPE. When developing the system it was considered that indicators by separate types of activity are wholly void of sense unless they are connected to current success factors and company's strategic goals.

In the course of carried out study key performance indicators for each of business dimensions were defined based on set individual and general goals; company's strategic map was made that contains a complex of proactive and main lagging indicators. At this stage both new indicators were developed and availability of traditionally used ones meeting company's strategic goals was estimated. It has been found that enterprises used a great deal of production indicators, which often duplicate each other, that's why its part was excluded form the KPI list.

At the same time issues for KPI selection for other units and business processes aren't examined in detail that determines the need for further studies concerning this area.

\section{References}

Andreev, A.F. (2011). Production costs on enterprises of oil and gas complex: theory and practice: [text]/ Andreev, A.F., Berezina, S.A. et al. / study guide. Edited by Andreev, A.F. Moscow: Gubkin Oil and Gas University, 224 c.

Becker B.I., Huselid, M.M., Ulrich, D. (2007). The HR-scorecard. Linking people, strategy and performance: transited from English. Moscow: "I.D. Williams" JSC, p. 161

Davydenko, E.A. (2008). Features of Balanced score cards conception use for small and medium national enterprises [Text]/ Davydenko, E.A. // Management v Rossii i za rubezhom, No.1, pp.125-127

Deberdieva, E.M. (2011). Corporate development strategy of oil and gas company/ Deberdieva, E.M., Lenkova, O.V. under the editorship of Korzhubaev, A.G. - Novosibirsk: Institute of Economics and Industrial Engineering of SB RAS, $168 \mathrm{p}$.

Deberdieva, E.M. (2014). Strategic maps as a planning basis in complex industrial oil and gas structures/ Deberdieva, E.M // Ekonomika i predprinimatelstvo, No.5-1, pp.371-374

Doran, G.T. (1981). There's a S.M.A.R.T. way to write management's goals and objectives/ George T. Doran // Management Review — Volume 70, Issue 11(AMA FORUM), pp. 35-36.

Drucker, Peter F. (2007). The Practice of Management [Text]/ Peter F. Drucker - Elsevier: Butterworth-Heinemann, $358 \mathrm{p}$.

Gershun, A. (2006). Technology of sustainable management [text]/ Gershun, A., Gorsky M., - Moscow: "Olimp-Buznes" CJSC, 416 p.

Hope, J. (2007). Beyond Budgeting: How Managers Can Break Free from the Annual Performance Trap/ Jeremy Hope, Robin Fraser $/$ translated from English. Moscow: Vershina, $272 \mathrm{p}$.

Isaeva, N.S. (2014). Performance evaluation of oil and gas companies' resource strategies based on Balanced Scorecard and performance indicators [Electronic resource]/ Isaeva, N.S. // Upravlenie ekonomicheskimi sistemami, No. 10 - access mode: http://www.uecs.ru/uecs70-702014/item/3089-2014-10-20-08-54-11

Kaplan, Robert S. (1996). The balanced scorecard: translating strategy into action/ Robert S. Kaplan, David P. Norton - M.: Harvard Business School Press, 322 p.

Kaplan, Robert S. (2004). Strategy maps: converting intangible assets into tangible outcomes/ Robert S. Kaplan, David P. Norton - M.: Harvard Business School Press, 512 p.

Klochkov, A.K. (2010). KPI and staff motivation: complete collection practical tools [Electronic resource]/ Klochkov, A.K - Moscow: Eksmo, access mode: http://www.alldirector.ru/wp-content/ uploads/2012/11/KPI-и-мотивация-персонала.pdf

Lenkova, O.V. (2011). Criterial basis of company's advantageous development strategy/ Lenkova, O.V., Osinovskaya, I.V. // Ekonomika v promyshlennosti, No.2, pp.10-13

Lenkova, O.V. (2011). Strategic decision theory [text]/ Lenkova, O.V., Osinovskaya, I.V, Shalakhmetova, A.V. Tyumen: Tyumen State Oil and Gas University, 224 p.

Maisel, Lawrence S. (1992). Performance measurement. The balanced score-card approach/ Lawrence S. Maisei // Journal of Cost Management, Summer, pp. 5-10.

Osinovskaya, I.V. (2013). Management decision-making algorithm in oil and gas structures of complex structure [text] / Osinovskaya, 
I.V., Plenkina, V.V, Lenkova, O.V. // Nauchnoe Obozrenie, No.1, pp. 262-267.

Panov, M.M. (2013). Company operation assessment and management system based on KPI. Moscow: Infra-M, 255 p.

Parmenter, David. (2007). Key Performance Indicators: developing, implementing and using winning KPI's. [Text]/ David Parmenter — New Jersey, USA: John Wiley \& Sons, inc., 233p.

Pechenaya, L.T. (2007). Enhancement of corporate governance mechanism in food industry/ Pechenaya, L.T, Bogomolova, I.P.// Menedzhment v Rossi i za rubezhom, No.5 pp. 90-95

Pereverzev, N. (2003). Business management using the BSC system [electronic resource]/ Pereverzev, N // Finansovy Director, No. 3 access mode: http://fd.ru/articles/1401-upravlenie-predpriyatiem-s-pomoshchyu-sistemy-bsc)

Permyakov, Y. (2012). Balanced Scorecard: case story [electronic resource]/ Permyakov, Y. // Finansovy Director, No.7 - access mode: http://fd.ru/articles/37938-sistema-sbalansirovannyh-pokazateley-primer-vnedreniya\#ixzz3REsfVL4i

Plenkina, V.V. (2013) Development of management decision in oil and gas structures/ Plenkina, V.V., Osinovskaya, I.V, Lenkova, O.V Germany, Saarbrucken: LAP LAMBERT Academic Publishing GmbH \& Co. KG, 92 p.

Rampersad, Hubert K. (2003). Total Performance Scorecard: redefining management to achieve performance with integrity [Text]/ H. K. Rampersad - Butterworth: Heinemann Business Books, $332 \mathrm{p}$.

Tonysheva, L.L. (2001). Development of learning management system in oil and gas business/ Tonysheva, L.L - Tyumen: Tyumen State Oil and Gas University, 447 p. 
ISSN 2039-2117 (online) ISSN 2039-9340 (print)
Mediterranean Journal of Social Sciences MCSER Publishing, Rome-Italy
Vol 6 No $3 \mathrm{~S} 3$ May 2015 